\title{
Insectoacaricide Activity of Thymol Against Menoponidae and Gamasid Mites Dermanyssus Gallinae
}

\author{
Safronov A.M. \\ Department of parasitology and veterinary inspection, \\ anatomy and anatomical pathology. S.N. Nikolski \\ Stavropol State Agrarian University, SSAU \\ Stavropol, Russian Federation \\ andriei.safronov@bk.ru
}

\author{
Lutsuk S.N. \\ Department of parasitology and veterinary inspection, \\ anatomy and anatomical pathology. S.N. Nikolski \\ Stavropol State Agrarian University, SSAU \\ Stavropol, Russian Federation
}

\begin{abstract}
This article presents data on the species composition, intensity and extensiveness of invasion in individual farms in the Shpakovskogo district of Stavropol Krai. The species composition of parasites is represented by ticks Dermanyssus gallinae and mallofags Menopon gallinae, Eomenacanthus stramineus and Goniocotes gallinae. There are the clinical signs in hens, such as anxiety, itching through the body, appearance of areas devoid of feather, redness and folding of the affected areas. Studies have been performed on the insectoacaricide activity of thymol against the parasites described above. We also conducted a series of experiments in which thymol was used for disinvasion of poultry farms from Dermanyssus gallinae ticks. And it was found that thymol is effective for 11 days, after this period the effectiveness of the drug decreased. In our opinion, thymol can be used as an alternative tool in the fight against dermanissiosis and mallophagosis or used in combination with other insectoacaricide drug.
\end{abstract}

Keywords - thymol, gamasid mites, menoponidae, insectoacaricide drug.

\section{INTRODUCTION}

Lately there has been a trend towards an increase in the spread of gamasid mites and menoponidae in chickens in individual farms on the territory of Stavropol Krai $[1,2,3]$. These ectoparasites cause tangible economic damage to poultry in the province, which manifests itself in reduced egg production and death of the birds [4]. These ectoparasites data can be vectors of several diseases dangerous for birds $[5,6,7]$. There is also evidence that the Red chicken mite may be a reservoir of dangerous diseases such as Lyme disease and Q fever [8].

Today there are many different insectoacaricide drugs; they have both advantages and disadvantages. The main disadvantages are the emergence of resistance among the ectoparasites and restrictions on products after processing insectoacaricide drug [9]. The aim of our work was inspired by testing the insectoacaricide actions as an alternative means to fight gamasid mites and menoponidae of hens.
Thymol is of natural origin; it is an integral part of the essential oils of Thýmus vulgári. In the past it was used in medicine and veterinary anthelmintic drug antiseptic, as well as one of the components of dental fillings [10,11]. Now it is actively used in beekeeping for treatment and prevention of varroatosis, acarapidosis, nosematosis, ascospherosis and rotten diseases of bees [12,13].

\section{RESULT AND DISCUSSION.}

The test took place at individual farms of Shpakovskogo district of Stavropol Krai.

Before conducting field tests on chickens, drug tests were conducted in vitro on isolated from hens gamasid mites Dermanyssus gallinae and menoponidae. The study was conducted at the Department of parasitology and veterinary inspection, anatomy and anatomical pathology of S.N. Nikolski Stavropol State Agrarian University.

Mathematical processing of all the obtained results was in Microsoft Office Excel.

In the experiment, we used thymol produced by company Unipharm in the form of water solutions. To test thymol in vitro, we chose 3 concentrations: $1 \%, 1.5 \%$ and $3 \%$. The first test of thymol took place on gamasid mites Dermanyssus gallinae. Mites were divided into 4 groups (10 ticks in each): in the first group we used $1 \%$ water solution of thymol (I), in the second group $-1.5 \%$ water solution of thymol (II), in the third group $-3 \%$ water solution of thymol (III), the fourth group was control; distilled water was used. Gamasid mites were placed in a Petri dish with filter paper, on which the preparation was applied in a volume of $1.5 \mathrm{ml}$, after which the dish was covered with a lid. Accounting for the death of ectoparasites was every 24 hours. Those mites believed to be dead that did not respond to mechanical irritation. The results are presented in table 1 .

Thus, from the data of table 1 it follows that thymol in all concentrations causes $100 \%$ death of mites Dermanyssus gallinae. In the control group, it was noted that all mites were alive for 24 hours. 
TABLE I. THE TEST RESULTS OF USING THYMOL ON GAMASID MITES DERMANYSSUS GALLINAE

\begin{tabular}{|c|c|c|c|}
\hline Groups & $\begin{array}{c}\text { The quantity } \\
\text { of mites in the } \\
\text { group }\end{array}$ & $\begin{array}{c}\text { The quantity of mites } \\
\text { killed after 24 hours }\end{array}$ & $\begin{array}{c}\text { Efficiency } \\
\text { index, \% }\end{array}$ \\
\hline I & 10 & 10 & 100 \\
\hline I I & 10 & 10 & 100 \\
\hline I I I & 10 & 10 & 100 \\
\hline $\begin{array}{c}\text { Control } \\
\text { group }\end{array}$ & 10 & 0 & 0 \\
\hline
\end{tabular}

Similarly, thymol was tested on menoponidae. The experiment was conducted with each species of menoponidae separately. Due to their lower resistance to insectoacaricide drug compared to gamasid mites, observation was carried out every 12 hours. The dead believed to be those ectoparasites that did not respond to mechanical irritation. The results are presented in table 2 .

TABLE II. THE RESULTS OF THE TEST OF USING THYMOL IN INSECTS MALLOPHAGA

\begin{tabular}{|c|c|c|c|}
\hline Groups & $\begin{array}{c}\text { The quantity of } \\
\text { menoponidae in the } \\
\text { group }\end{array}$ & $\begin{array}{c}\text { The quantity of } \\
\text { menoponidae killed } \\
\text { after } 24 \text { hours }\end{array}$ & $\begin{array}{l}\text { Efficiency } \\
\text { index, \% }\end{array}$ \\
\hline \multicolumn{4}{|c|}{ Menopon gallinae } \\
\hline $\mathrm{I}$ & 10 & 10 & 100 \\
\hline I I & 10 & 10 & 100 \\
\hline I I I & 10 & 10 & 100 \\
\hline $\begin{array}{l}\text { Control } \\
\text { group }\end{array}$ & 10 & 0 & 0 \\
\hline \multicolumn{4}{|c|}{ Eomenacanthus stramineus } \\
\hline $\mathrm{I}$ & 10 & 10 & 100 \\
\hline I I & 10 & 10 & 100 \\
\hline I I I & 10 & 10 & 100 \\
\hline $\begin{array}{c}\text { Control } \\
\text { group }\end{array}$ & 10 & 0 & 0 \\
\hline \multicolumn{4}{|c|}{ Goniocotes gallinae } \\
\hline I & 10 & 10 & 100 \\
\hline I I & 10 & 10 & 100 \\
\hline I I I & 10 & 10 & 100 \\
\hline $\begin{array}{l}\text { Control } \\
\text { group }\end{array}$ & 10 & 0 & 0 \\
\hline
\end{tabular}

Thus, from the data of table 1 it follows that thymol in all concentrations causes $100 \%$ death of insects Mallophaga. In the control group, it was noted that all menoponidae were alive for 24 hours.

Based on the results of the in-vitro study of thymol, a concentration of $1 \%$ was chosen for further research, as it showed the same high concentrations as those of thymol.

The study of the toxic properties of thymol was carried out in accordance with the "Guidelines for the experimental (preclinical) study of new pharmacological substances" [14].

Parameters of toxicity of the drug in acute experience with a single-tip application of mature, conventional, non-linear, heterosexual white mice, weighing 18-20 g (10 heads), and using clinically healthy breeds of Pomrah aged 6-7 months (10 heads). Observation of animals was carried out continuously during the first day after treatment with thymol. Then state of animals was noted twice a day for 2 weeks. The general status and behavior of animals, the state of neuromuscular and vegetative functions, skin (feather) covering, eating food, and water consumption were recorded. The evaluation of the toxicity of a $1 \%$ thymol solution in white mice was as follows. The solution was sprayed over the entire surface, including the head, with the help of a spray, until the coat was completely soaked. The animals were divided into 2 groups of 10 animals each. Group 1 was treated with a $1 \%$ solution of thymol, and group 2 was control - it was treated with distilled water. Over the entire observation period, the general condition of the experimental animals did not change. The only negative effect of the solution was irritation of the nasal mucosa, which manifested itself in the form of sneezing and lasted for the first day. The results are presented in table 3 .

TABLE III. ASSESSMENT OF THE TOXICITY OF $1 \%$ SOLUTION OF THYMOL IN MICE

\begin{tabular}{|c|c|c|c|}
\hline Groups & $\begin{array}{c}\text { The quantity of } \\
\text { animals in the } \\
\text { group }\end{array}$ & $\begin{array}{c}\text { The quantity of } \\
\text { dead animals }\end{array}$ & $\begin{array}{c}\text { The percentage of } \\
\text { animals that have } \\
\text { developed side } \\
\text { effects }\end{array}$ \\
\hline Group 1 & 10 & 0 & $100 \%$ \\
\hline Group 2 & 10 & 0 & $0 \%$ \\
\hline
\end{tabular}

Conducting a toxicity test on hens, in order to completely moisten the feather cover and in order to completely moisten the feather covering so that the solution got on the skin of the bird, we used bird bathing in a $1 \%$ solution of Thymol heated to a temperature of $36-37^{0} \mathrm{C}$. A control group was bathed in distilled water. The results are presented in table 4 .

TABLE IV. TABLE 4. ASSESSMENT OF THE TOXICITY OF $1 \%$ SOLUTION OF THYMOL IN HENS

\begin{tabular}{|l|l|l|l|}
\hline Groups & $\begin{array}{l}\text { The quantity of } \\
\text { animals in the } \\
\text { group }\end{array}$ & $\begin{array}{l}\text { The quantity } \\
\text { of dead } \\
\text { animals }\end{array}$ & $\begin{array}{l}\text { The percentage of } \\
\text { animals that have } \\
\text { developed side effects }\end{array}$ \\
\hline $\begin{array}{l}\text { Group } \\
1\end{array}$ & 10 & 0 & $0 \%$ \\
\hline $\begin{array}{l}\text { Group } \\
2\end{array}$ & 10 & 0 & $0 \%$ \\
\hline
\end{tabular}

As can be seen from table 4 , in the group all experimental birds were alive. None of the birds developed side effects.

The next stage of the research was to test a $1 \%$ water solution of thymol on the hens with the natural invasion of gamasid mites and menoponidae in the field. In the experimental hens, the species composition of the 
ectoparasites, as well as the intensity and extensivity invasion, was previously used. The species composition of parasite mites Dermanyssus gallinae is presented in Fig. 1, "menoponidae Menopon gallinae" - Fig. 2, "Eomenacanthus stramineus - Fig. 3, and Goniocotes gallinae - Fig. 4.

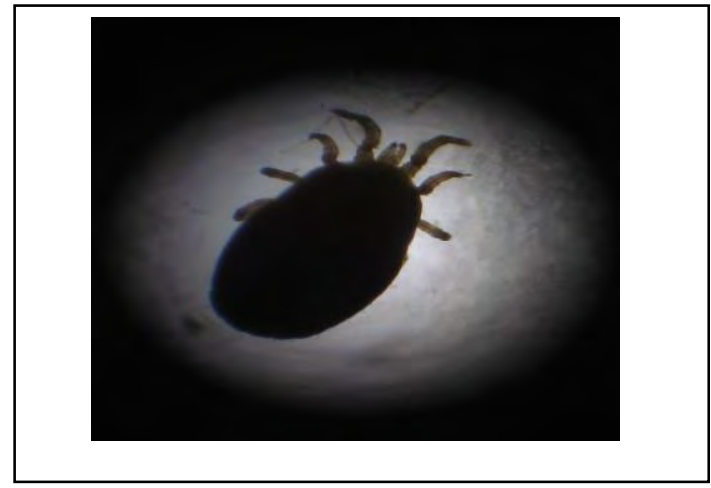

Fig. 1. Dermanyssus gallinae

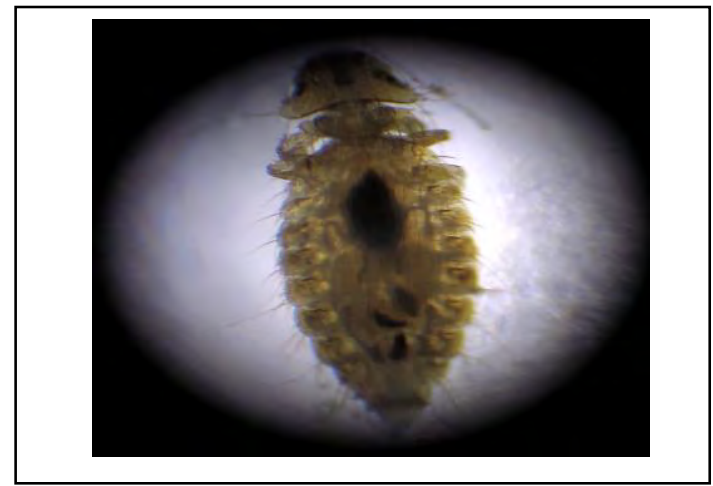

Fig. 2. Menopon gallinae

When monitoring a sick bird, we pointed out the concern chickens plucking their feathers by the beak for a long time, these are areas without pens, most often in the area of cloaca, back (Fig. 5,6) and the back surface of the wings. At night hens also worried, did not sleep, sometimes fell off the perch. When inspecting the skin, detected areas deprived of pen were with reddened skin, skin thickened compared to non-affected areas, there was scratching, skin folding was also observed (Fig. 7), the surface of the lesions covered with scales of the epithelium. (Fig. 8).

It is worth noting that the clinical signs were more intense on chickens; the roosters did not have such an intense loss of feather.

Examining the feathers in the area of the cloaca, the authors found the attachment of the eggs of the menoponidae (Fig. 9).

Parasites were collected to establish the intensity of invasion according to the method of Fomicheva E.D. [15]. To do this, the bird was placed in an appropriately sized plastic bag, while leaving only the head outside. Cotton wool (3-4 grams), well impregnated with ether, was put in the package beforehand. Then, after 5 minutes, with light movements of the fingers, penetrating between the wings and down of the bird, above the white cloth, tousled its cover and shook off ectoparasites until the insects stopped getting enough sleep. The parasites found with this were collected with a moistened brush in separate tubes from each bird and fixed in $70 \%$ alcohol.

To assess the intensity of invasion by ectoparasites of birds, we used the scale of the Blagoveshchenskiy D.I.:

1 Few - up to 10 individuals.

2 Moderately - up to 100 individuals.

3 Many - up to 1000 individual.

4 Mass - more than 1000 individual.

Data on the intensity of invasion are presented in table 5.

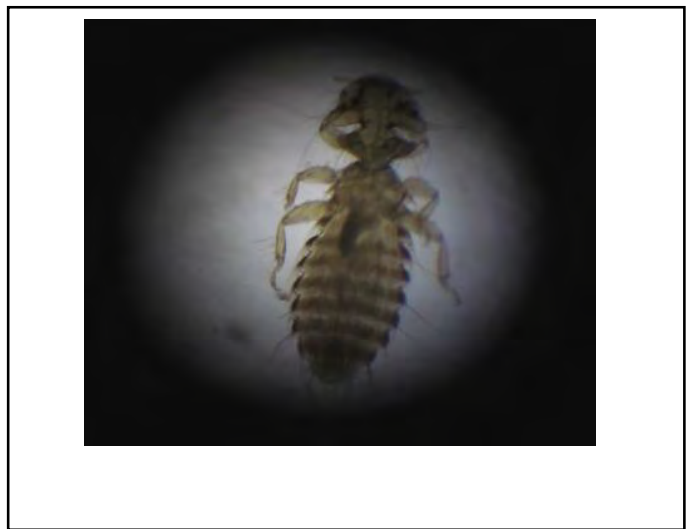

Fig. 3. Eomenacanthus stramineus

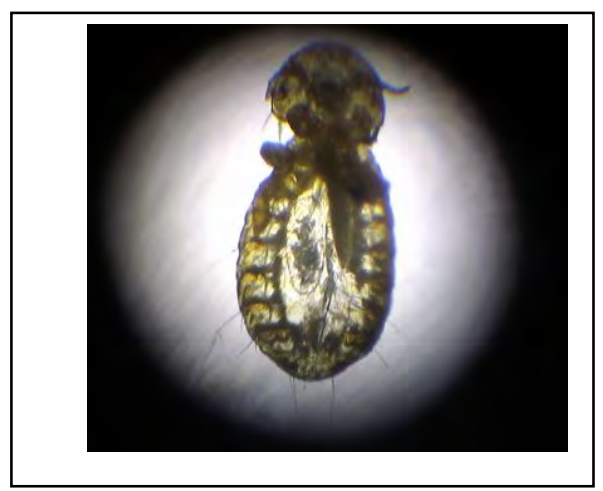

Fig. 4. Goniocotes gallinae

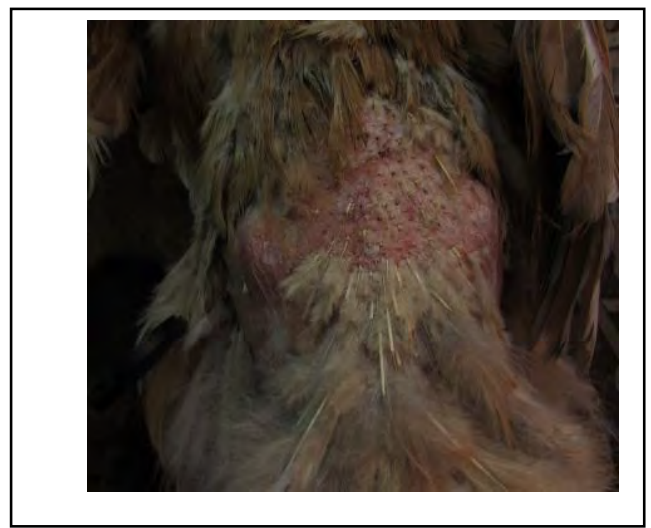

Fig. 5. Skin area without pens 


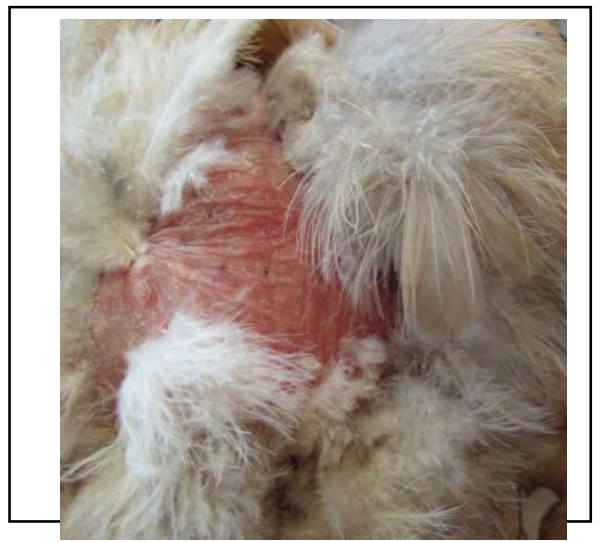

Fig. 6. Redness and folding of the skin

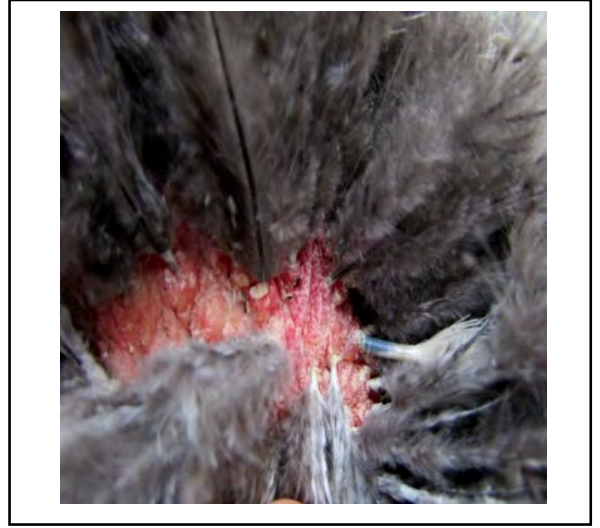

Fig. 7. Redness and folding of the skin

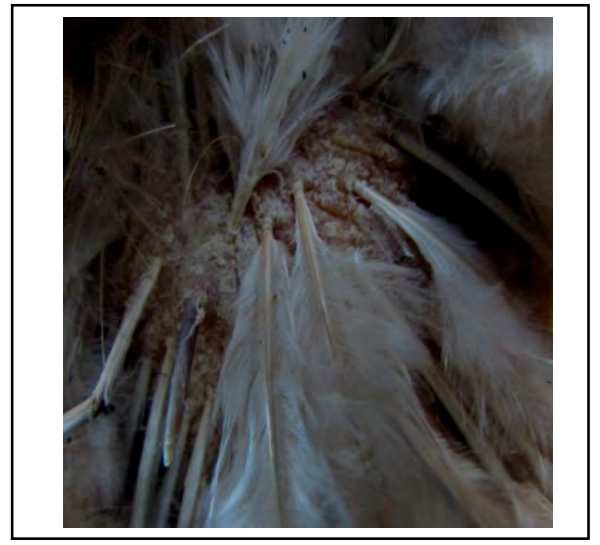

Fig. 8. Scales on the skin surface

As can be seen from the data of table 5, the invasion of menoponidae prevailed over the invasion of Dermanyssus gallinae, and the highest level of intensity and extension of invasion among all the parasites in Menopon gallinae.

For the test, the chickens were divided into 2 groups (50 animals each), after treatment, both groups were kept together. The first group was treated with thymol, it was an experimental group. The second one was controlled with distilled water. Here we also used the bathing method to process the birds. The treatment was carried out in the yard of the house in calm weather at an ambient temperature of $22^{\circ} \mathrm{C}$ and humidity of $30 \%$. A thymol solution warmed to $36-37^{\circ} \mathrm{C}$ was used. After treatment, both groups were monitored and daily ectoparasites were counted. Counting was carried out with 10-15 individuals from the group, the bird was chosen randomly. It is worth noting that after treatment in the used solution of thymol, a lot of dead menoponidae and red chicken mites were discovered. Counting results of ectoparasites are presented in tables 6 and 7

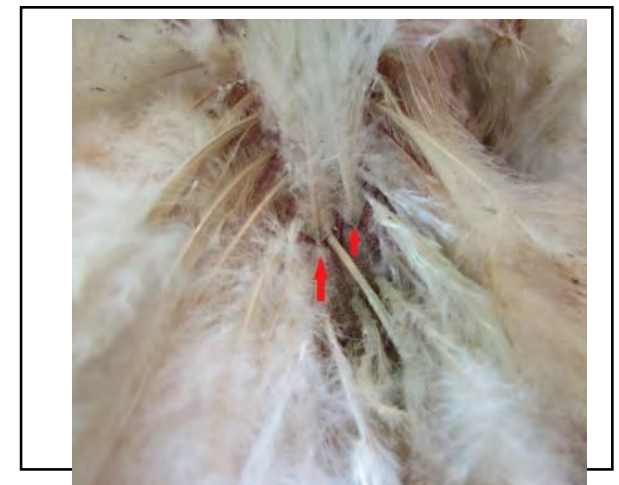

Fig. 9. Place of attachment of menoponidae eggs (indicated by arrows)

TABLE V. INTENSITY AND EXTENSION OF INVASION

\begin{tabular}{|c|c|c|}
\hline $\begin{array}{c}\text { Species } \\
\text { ectoparasites }\end{array}$ & $\begin{array}{c}\text { Intensity invasion } \\
\text { instance / head }\end{array}$ & $\begin{array}{c}\text { Extension of } \\
\text { invasion, \% }\end{array}$ \\
\hline $\begin{array}{c}\text { Dermanyssus } \\
\text { gallinae }\end{array}$ & $40 \pm 7.32$ & 70 \\
\hline Menopon gallinae & $120 \pm 11.45$ & 100 \\
\hline $\begin{array}{c}\text { Eomenacanthus } \\
\text { stramineus }\end{array}$ & $85 \pm 5.53$ & 85 \\
\hline
\end{tabular}

TABLE VI. DYNAMICS OF INTENSITY INVASION OF MITES DERMANYSSUS GALLINAE

\begin{tabular}{|c|c|c|c|c|c|c|}
\hline \multirow{2}{*}{ Groups } & \multicolumn{6}{|c|}{ Intensity invasion. instance / head } \\
\cline { 2 - 7 } & 1 day & 5 day & 10 day & 15 day & 20 day & 25 day \\
\hline $\begin{array}{c}\text { Experiment } \\
\text { al group }\end{array}$ & 0 & 0 & 0 & 0 & 0 & $7 \pm 2$ \\
\hline $\begin{array}{c}\text { Control } \\
\text { group }\end{array}$ & $40 \pm$ & $40 \pm$ & $40 \pm$ & $40 \pm$ & $40 \pm$ & $40 \pm$ \\
& & 7.32 & 7.32 & 7.32 & 7.32 & 7.32 \\
\hline
\end{tabular}

As can be seen from the tabular data, a $1 \%$ solution of thymol was very effective against menoponidae during the entire observation period in experimental animals; these ectoparasites were not detected. As to gamasid mites, thymol was less effective by the 25th day of observation, gamasid mites were again found on the bird, but in a lower invasion compared to the control. 
TABLE VII. DYNAMICS OF INTENSITY INVASION OF INSECTS MALLOPHAGA

\begin{tabular}{|c|c|c|c|c|c|c|}
\hline \multirow{2}{*}{ Groups } & \multicolumn{6}{|c|}{ Intensity invasion. instance / head } \\
\hline & 1 day & 5 day & 10 day & 15 day & 20 day & 25 day \\
\hline \multicolumn{7}{|c|}{ Menopon gallinae } \\
\hline Experimental group & 0 & 0 & 0 & 0 & 0 & 0 \\
\hline Control group & $120 \pm 11.45$ & $120 \pm 11.45$ & $120 \pm 11.45$ & $120 \pm 11.45$ & $120 \pm 11.45$ & $120 \pm 11.45$ \\
\hline \multicolumn{7}{|c|}{ Eomenacanthus stramineus } \\
\hline Experimental group & 0 & 0 & 0 & 0 & 0 & 0 \\
\hline Control group & $85 \pm 5.53$ & $85 \pm 5.53$ & $85 \pm 5.53$ & $85 \pm 5.53$ & $85 \pm 5.53$ & $85 \pm 5.53$ \\
\hline \multicolumn{7}{|c|}{ Goniocotes gallinae } \\
\hline Experimental group & 0 & 0 & 0 & 0 & 0 & 0 \\
\hline Control group & $67 \pm 4.18$ & $67 \pm 4.18$ & $67 \pm 4.18$ & $67 \pm 4.18$ & $67 \pm 4.18$ & $67 \pm 4.18$ \\
\hline
\end{tabular}

TABLE VIII. DISINVASION OF POULTRY HOUSES.

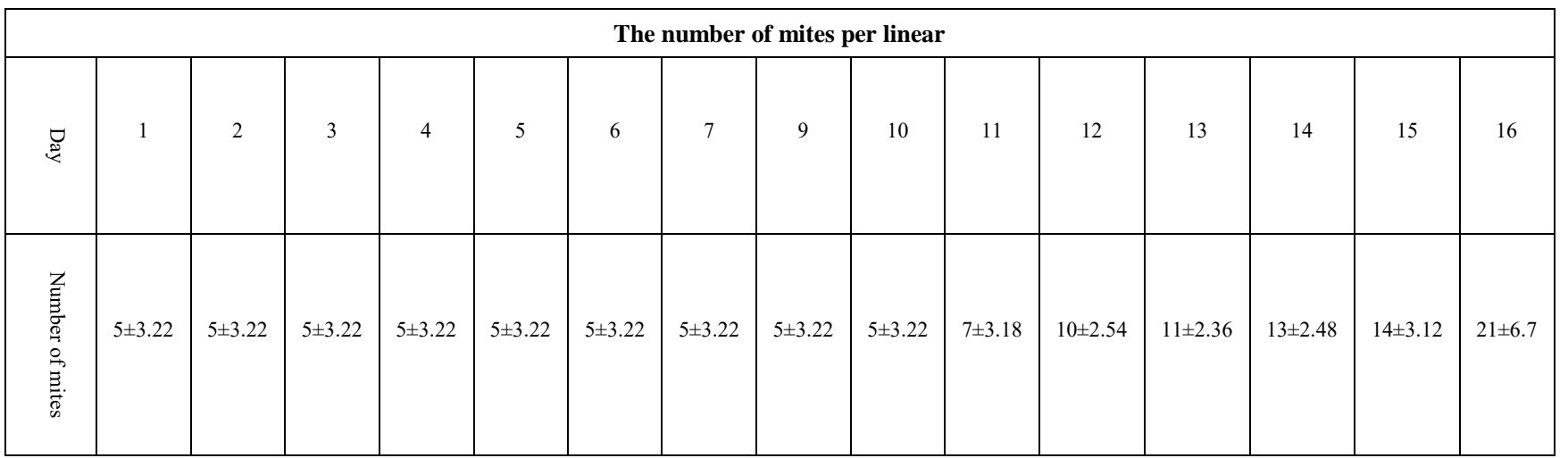

We also conducted a series of experiments in which we used a $1 \%$ solution of thymol at disinvasion poultry houses from Dermanyssus gallinae. Previously, an estimate was made of the number of mites of a room according to the method by V.M. Speranskaya. To do this, a sheet of white paper was pushed under the bar of the persecution, the cage was hit with a stick, the bottom surface was scraped with brush roosts, after which mites fell onto the paper. The degree of infection at home was determined by the number of samples collected from 1 meter:

1 weak degree, the number of mites per linear meter no more than 10 individuals;
2 average degree, the number of mites per linear a meter is not more than 100 individuals;

3 strong degree, the number of mites per 1 running meter up to 500 individuals;

4 very strong degree, the number of mites per 1 running meter more than 500 individual.

During the study period, about 10 poultry houses were examined with an average number of mite's level of $150.4+$ 9.09 ticks per running meter. For disinfection, a hot water solution of $1 \%$ thymol $\left(80^{\circ} \mathrm{C}\right)$ was used after mechanical cleaning of the room by spraying. After processing the premises, daily counting of ticks in the poultry-farming 
premises was carried out according to the Speranskaya method, which was described above. The results are presented in table 8.

As can be seen from table 8 , the pronounced effect of thymol was persisting for 11 days. After that there was a decrease in the effectiveness of the drug, which is especially pronounced on day 16 after treatment.

\section{CONCLUSION}

Thymol was effective against mites Dermanyssus gallinae and menoponidae Menopon gallinae, Eomenacanthus stramineus, and Goniocotes gallinae at a concentration of $1 \%$. After a single treatment, the protective effect against ticks and menoponidae persists for 15 and 25 days, respectively. This drug is harmless when applied to the skin, which is tested laboratory on white mice and chickens. The only side effect was irritation of the nasal mucosa, this phenomenon was observed only in mice, which was not observed in chickens. Thymol water solution was also used to disinfect poultry premises and was effective for 11 days. After that period, the efficiency of the drug decreased. In our opinion, thymol can be used as alternative drugs in the fight against dermanissiosis and mallophagosis or used in combination with other insectoacaricide drugs.

\section{References}

[1] A.M Safronov, "The species composition of ectoparasites in the individual farms of the North Caucasus region," Actual problems of veterinary biology, vol. 4 (36), pp. 22-25, 2017
[2] O.M. Lyahova, B.K. Cotti "Menoponidae (Mallophaga insect) on birds in Central Ciscaucasia", Parasitology, vol. 5, pp. 461-474, 2010

[3] O.M. Lyakhov, "Zoogeographical characteristic of Menoponidae lice Central Ciscaucasia", Fauna of Stavropol, Vol. 14, pp. 84-87, 2007.

[4] R.M. Akbaev, "The test of the acaricidal effect of the new domestic "Vuran" drug on Dermanyssus gallinae mites under laboratory conditions," Veterinary medicine, vol. 2-M, pp. 26-27, 2006.

[5] C.V. Moro, S. Desloire, C. Chauve, L Zenner, "Detection of Salmonella sp. in Dermanyssus gallinae using a polymerase chain reaction based on FTA," Med Vet Entomol, vol. 2, pp.148-152, 2007.

[6] J. Chirico, H. Eriksson, O. Fossum, D. Jansson, "Red bird mite, Dermanyssus gallinae, potential vector of Rrysiopathiae Erysipelothrix, causing chromos in chickens," Med Vet Entomol, vol. 2, pp. 232-234, 2003.

[7] D Petrov, "Study of Dermanyssus gallinae as a carrier of Pasteurella multocida," Vet Honey Science, vol. 5, pp. 32-36, 1975.

[8] L. Salandra, G. Lomuto, M.A. Cafiero, "First report of Coxiella burnetii and Borrelia burgdorferi sensu lato in poultry red mites, Dermanyssus gallinae (Mesostigmata, Acari)", New Microbes New Infect, vol. 23, pp.103-109, 2018.

[9] I.A. Arkhipov "Anthelmintics: pharmacology and application," 2009, pp. $12-13$.

[10] C.B. Timofeev, "Veterinary dentistry," 2006, p. 38.

[11] V.I. Maslenikova, "Vegetable and synthetic acaricides in the treatment of bees varraotoza," Beekeeping, vol. 4-M, pp. 31-34, 2008.

[12] A.A. Kotova, "A new means of fighting bee varraotoza, "Problems of veterinary sanitation, hygiene and ecology, vol. 1 (7), pp. 112-116, 2012.

[13] A.I. Muravskaya, "Treatment of mixed forms of infectious diseases of bees," Collection of research work on beekeeping, pp.185-189, 2005.

[14] P.U. Khabriev, "Manual on experimental (preclinical) study of new pharmacological substances," 2005

[15] E.D. Fomichev, "A new method of collecting lice (Mallophaga) from poultry," Actual problems of the humanities and natural sciences, vol. 5 (64), pp. 38-41, May 2014. 